Flora Blanchon (dir.), Aller et Venir. Faits et perspectives (Coming and Going. Facts and Perspectives)

Paris, Presses de l'Université de Paris-Sorbonne, 2002, 389 p.

\title{
Michel Jan
}

\section{OpenEdition}

\section{Journals}

Édition électronique

URL : http://journals.openedition.org/chinaperspectives/839

DOI : 10.4000/chinaperspectives.839

ISSN : 1996-4617

Éditeur

Centre d'étude français sur la Chine contemporaine

Édition imprimée

Date de publication : 1 juillet 2004

ISSN : 2070-3449

\section{Référence électronique}

Michel Jan, «Flora Blanchon (dir.), Aller et Venir. Faits et perspectives (Coming and Going. Facts and Perspectives) », China Perspectives [En ligne], 54 | July- August 2004, mis en ligne le 25 avril 2007, consulté le 21 septembre 2020. URL : http://journals.openedition.org/chinaperspectives/839 ; DOI https://doi.org/10.4000/chinaperspectives.839

Ce document a été généré automatiquement le 21 septembre 2020.

(c) All rights reserved 


\title{
Flora Blanchon (dir.), Aller et Venir. Faits et perspectives (Coming and Going. Facts and Perspectives)
}

\author{
Paris, Presses de l'Université de Paris-Sorbonne, 2002, 389 p.
}

\author{
Michel Jan
}

\section{NOTE DE L'ÉDITEUR}

Translated from the French original by Michael Black

"After the first volume of Coming and Going, which was mainly devoted to ideas suggested by the notion of travel", explains Flora Blanchon, "this second volume has ambitions that one might call technical". The diversity of approach, historical, geographical and even technical is indeed what characterises this collection of texts on travel in several Asian countries.

2 The first part is given over to the river and sea routes, beginning with "The economic and legal aspects of transport by rivers and sea in ancient India", by Irma Piovano. "Sea routes and ports of ancient Sri Lanka" by Osmund Bopearachchi, is an assessment of the research carried out by the French archaeological co-operation mission in Sri Lanka on the western and southern coasts of the island from 1994 to 1998. The results of these excavations are accompanied by a useful comparison with the texts of the classical Greek and Latin authors. "Zheng He, narratives, compass and maps" by Michel Didier, sets out, based on several original narratives, the state of knowledge at the beginning of the fifteenth century, during the Ming era, in the field of navigation: ships, compasses, charts, nautical instruction, tides; the role of the pilots was the determining factor.

"The description of the Grand Canal of China in the first travel narratives, and its impact in the West" by Isabelle Landry-Deron, is based on the accounts of travellers from Europe between the sixteenth and eighteenth centuries. Their itinerary, which 
was practical and marked out, followed the usual and compulsory route towards the capital of the empire, which they entered via Canton, the unavoidable place of passage. Most were ecstatic at the feats of construction, to the point of advising that they should be used as an inspiration for the construction of canals in their own countries. In "Transpeninsular routes on the Malay peninsula in the $\mathrm{V}^{\text {th }}$ to XIV ${ }^{\text {th }}$ centuries", Michel Jacq-Hergoualc'h reminds us that the crossing by land was in use by the beginning of our era, and was sometimes preferred to the long way round the peninsula by the southern sea route. Traces of settlements on both sides testify to the existence of commercial exchanges. "Journey into another world", by Paul Waley, is a study of the importance of the ferries and ferry-boats, which supplemented the bridges over the river Sumida in ancient Edo-Tokyo. Whether in pictorial or literary representations, or in everyday reality, these boats were part of the urban landscape until their disappearance with the advent of industrial growth in the 1920s.

The second part is devoted to "Land routes and means of transport"; Lucette Boulnois, in "Chinese road construction policy in the autonomous region of Tibet (1950-2001)" describes the main routes into this immense region, while emphasising the strategic importance of land communication routes. "The maps of ancient China" by Flora Blanchon presents maps dating from the third and second centuries $\mathrm{BC}$, which were discovered in 1973 in Hunan, and in 1986 in Gansu. Despite the limited territories they cover, they show the exceptional level of Chinese knowledge of cartography by that time. Marie-Alexandrine Martin, on "Collective travel and means of transport among the Khmer", shows how much the political events of the end of the last century, beginning in the 1970s, altered social practices in Cambodia. Forsaking many traditional behaviours for economic and security imperatives and migration to the cities, both men and women use motorised transport at the cost of the environment, not to mention peace and quiet, long a characteristic of the country. Denise Bernot shows us the secrets of the making of the "Burmese cart", evidence of which is found from the seventeenth century, while Claude Balaize introduces us to the epic story of the Saigon xich-lo dap (bicycle rickshaw), from its emergence in the 1930s to now as it faces competition from polluting motorised vehicles.

5 The third part is devoted to rail transportation. "The high-speed train in Korea and national and regional development policy", by Lee Kyung-Chul, analyses the advantages of the high-speed train, its impact on the environment, the local political rivalries born of its construction and their consequences-delays and cost overruns. The original approach of Sylvie Guichard-Anguis ("Trains and perceptions of space in children's literature") takes us into the world of the illustrated dream, and of the themes connected to rail transport in Japan, where the train dominates travel. "Journey by train from China to Vietnam in March 1978" swiftly recalls a crossing from Peking to Hanoi by Didier and Marie-Joëlle Sicard. "Entering Asia on the Transsiberian express" by Ivan P. Kamenarovik, will gratify those who dream of making such a journey, with its descriptions and spontaneous remarks. Lastly, Françoise Aubin embarks on a compilation of studies by experts in order to deal with the "Absolute Journey: the nomadic pastoralism of the Mongols".

6 Deliberately varied and sometimes picturesque, this book is disconcerting in the diversity of subjects treated and by the unequal quality of the texts, some being rich, while others remain superficial. Transportation in Asia, in its modern and contemporary aspects, whether by sea, rail or other means, deserves more organised 
analyses. Proofreading would also have made it possible to avoid inaccuracies and errors of transcription. 